\title{
Comparative analysis of company's financial performance before and after tax amnesty; evidence from Indonesia
} Ratno Agriyanto ${ }^{1}$, Della Aprilia ${ }^{2}$

1,2Faculty of Islamic Economics and Business, UIN Walisongo Semarang, Indonesia

\begin{abstract}
Purpose - The purpose of this study is to analyze differences in financial performance before and after the tax amnesty was applied until the third period.

Method - This research uses a comparative method with a quantitative approach. The data collection technique used the documentation method. The research data were in the form of annual reports and financial reports of issuers of the Indonesia Stock Exchange. The results showed the financial performance before and after the tax amnesty up to the third period in the property and real estate sub-sector companies.
\end{abstract}

Result - The result shows a significant difference between before and after the tax amnesty until the third period. However, there is no significant difference between Debt to Equity Ratio and Return on Equity before and after the tax amnesty until the third period. The analysis results up to the third period regarding company value shows that there are differences in company value before and after the tax amnesty up to the third period.

Implication - The study offers alternative perspective about tax amnesty. Most of the time companies are reluctant to engage with tax payment.By applying tax amnesty, both ruling government and companies are both be benefited.

Originality - This study is among few studies about the impact of tax amnesty on financial performance in Indonesia.

Keywords: tax amnesty, debt to equity ratio, total asset turnover, return on investment (ROI), Tobin's Q 


\section{Introduction}

Taxes are the main source of income for the Indonesian state. Tax is an obligation for every citizen of Indonesia. Law Number 28 Year 2007 Article 1 concerning General Provisions and Taxation

JIEMB | 114 states that tax is payable mandatory contribution to the state of the individual or entity which is coercive under the law without any direct return and shall be utilized for the needs of the state for the greatest prosperity of the people (Law Number 28, Year 2007). However, the data show that the realization of tax revenues has fluctuated.

Based on Figure 1, it can be seen that the realization of the tax revenues has decreased quite significantly from 2014 to 2015 and 2016. In 2014 the realization of tax revenue reached Rp985 T or $91.56 \%$ of the initial target of Rp1,072 T. In 2015, the realization has decreased quite drastically, reaching $\mathrm{Rp} 1,055 \mathrm{~T}$ or $81.96 \%$ of the initial target of Rp1,294 T. In 2016, it decreased again from the previous year, which only realized $81.59 \%$ or Rp1,105 T from the initial target of Rp1,355 T. In 2017, the realization of tax revenues again increased from the previous year, reaching $89.67 \%$ or $\mathrm{Rp} 1,151 \mathrm{~T}$ from the initial target of Rp1,284 T (Director General of Tax, 2019). The tax revenue target that is difficult to achieve due to the large number of tax potentials that is difficult to reach has led the government to issue a Tax Amnesty policy.

It is hoped that the tax amnesty policy can also improve financial performance and company value, increasing the company's financial performance through the presentation of assets and liabilities which will certainly have an impact on equity.

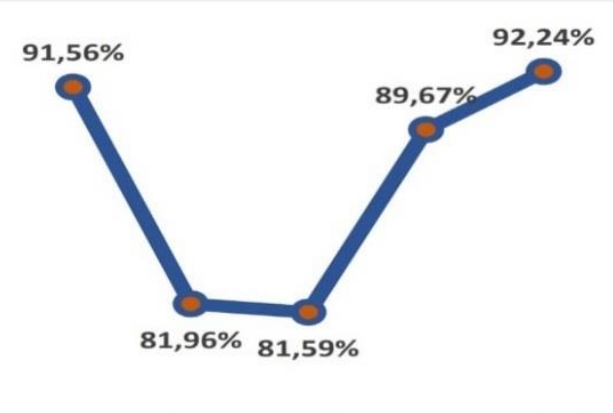

2014201520162017 2018*

Figure 1. Actual tax revenue target 
PSAK 70 stipulates that the difference between assets and liabilities is an additional paid-in capital (IAI PSAK 70, 2016).

Various studies have been conducted to look at the effectiveness of tax amnesty, but they revealed different results . Head of Mandiri Sekuritas Research, Jhon Rachmat, said that the tax amnesty would strengthen the capital inflow resulting from the repatriation of assets of Indonesian citizens who had been hiding abroad. According to him, there are 3 sectors that benefit the most from this tax amnesty, i.e the chancellor of real estate and property, infrastructure and supporting industries, construction and materials (Klinik Pajak, 2020).

Rinaldi (2017) found that the company value calculated by PBV (Price to Book Value) and Tobin's Q ratio decreased after the tax amnesty policy was implemented. Ariani, Afufudin, and Cholid (2018) found that there were significant changes in Current Ratio, Debt to Equity Ratio, Total Asset Turnover and Return on Equity before and after the implementation of the third period of 2016 tax amnesty in textile companies and garments listed on the IDX. However, the research of Nabila and Nurdin (2019) analyzed the comparison of company value before and after the tax amnesty policy in the textile and garment sector found different result. They found that there was no significant difference in company value between before and after the third period of tax amnesty in the textile and garment sub sector companies.

This study has originality, namely the addition of variables and the study period. This study presents financial performance variables as measured by the Return on Investment ratio and the research period carried out is tax amnesty until the third period which lasts from July 1, 2016 to March 31, 2017. Based on the background description above, the purpose of the study is to analyze differences in the financial performance of companies before and after Tax Amnesty.

\section{Literature review}

\section{Agency theory}

Agency theory describes two conflicting economic actors, namely the principal and the agent. An agency relationship is a contact where one or more people (principal) order another person 
(agent) to perform a service on behalf of the principal and authorize the agent to make the best decisions for the principal (Renaldi, 2015). In the context of this research, the government is the principal while the company is the agent. The government, acting as the principal, orders companies to pay taxes in accordance with tax laws. Agency theory assumes that companies as agents prioritize their interests in optimizing company profits so as to minimize burdens, including tax burdens, by avoiding taxes.

Openness is needed between the principal and the agency, because openness will reduce prejudice (Departemen Agama, 206). This prejudice will lead to ethics which has an impact on the tendency of dishonest behavior. Honest behavior is a very noble behavior and honesty is the basis of life in society. Honesty concerns all matters of life and the interests of many people. As it is found in al-Qur'an surah at-Taubah verse 119 which means

"O you who believe, fear Allah, and you should be with people who are true (honest)".

Openness in tax amnesty behavior is also important for the success of government programs. Tax amnesty is an amnesty or elimination of punishment given by the head of state to a person or group of people who have committed certain tax crimes. The verse of al-Qur'an which can be used as the foundation for the concept of tax amnesty is surah an-Nisa verse 48 which means

"Indeed, Allah will not forgive the sin of shirk, and He will forgive all sins other than (shirk), for whom He wills. Anyone who associates partners with Allah, then indeed he has committed a grave sin" (Dept Agama, 2005).

\section{Difference in current ratio before and after tax amnesty}

Current ratio is the ratio to measure the company's ability to pay short-term obligations or debts that are due immediately with available current assets (Rahardjo, 2007). Participating in the tax amnesty program, taxpayers must disclose all of their assets both domestically and abroad that have not been reported in the last SPT PPh. Assets located abroad are repatriated or transferred to Indonesia, so that the flow of repatriated funds can increase the company's assets in the financial statements and will have an impact on increasing the company's current ratio, the higher this ratio, the better the company's financial performance. Research by Khatami, Rustam, and Sulasmiyati (2017) stated that there was a significant 
difference in the Current Ratio between before and after carrying out an IPO (Initial Public Offering). Based on the formulation of the hypothesis, the first hypothesis in this study is:

$\mathrm{H} 1$ : There is a difference in the liquidity ratio (Current Ratio) before and after the tax amnesty until the third period.

Difference in debt to equity ratio before and after tax amnesty

Debt to equity ratio is the ratio used to measure the proportion of debt to equity (Hery, 2016). Debt is an obligation a company has that must be paid at a later date. If the company's debt is smaller than the company's capital, the better the company is. The tax amnesty system recognizes assets and debts that were not previously reported by the company. The difference between the assets and the liabilities is recognized as additional paid-in capital. The smaller the debt to equity ratio, the better the company's financial performance is. Research by Azhar, Rella, and Yuniawan (2012) stated that there was a significant difference in the solvency ratio (debt to equity ratio) of manufacturing companies listed on the Indonesia Stock Exchange before and after the 2008 tax reform. Based on the formulation of these hypotheses, the second hypothesis in this study is:

$\mathrm{H} 2$ : There is a difference in the leverage ratio (Debt to Equity Ratio) before and after the tax amnesty until the third period.

\section{Difference in total asset turnover before and after tax amnesty}

Total asset turnover is the ratio used to measure the extent to which the company's ability to produce sales of all its assets. The flow of repatriated funds generated from the tax amnesty program triggered an increase in the amount of company assets. The higher the company's assets, the more flexibility it is to create more innovative products and expand its products. The higher the level of sales generated from these assets. The higher this ratio, the better the company's financial performance is. Based on the formulation of the hypothesis, the third hypothesis in this study is:

H3: There is a difference in the activity ratio (Total Asset Turnover) before and after the tax amnesty until the third period. 


\section{Difference on return on equity before and after tax amnesty}

Return on Equity is the ratio used to measure the ability of own capital to generate profits for all shareholders, both common and preferred stock (Azhar et al., 2012). Return on Equity is used to determine the ability of a company to generate profits with equity. Disclosure of company's tax amnesty assets has an impact on an increase in additional paid-in capital. The greater the Return on Equity generated, the more effective and efficient use of company equity is to generate income. The higher this ratio, the better the company's financial performance is. Research by Khatami et al., (2017) stated that there was a significant difference in Return on Equity between before and after conducting an Initial Public Offering (IPO). Based on the formulation of the hypothesis, the fourth hypothesis in this study is:

$\mathrm{H} 4$ : There is a difference in the profitability ratio (Return on Equity) before and after the tax amnesty until the third period.

\section{Difference on return on equity before and after tax amnesty}

Return on investment is the ratio used to measure the company's ability to generate profits which will be used to cover the investment issued (Fahmi, 2012). The flow of repatriated funds generated from the tax amnesty program triggered an increase in the company's assets. The higher the company's assets, the free the company will be to invest as much as possible. The profit obtained from investment is higher. The turnover speed of assets used for company operations also greatly affects the rate of Return on Investment. Research by Azhar et al., (2012) showed that there was a significant difference in Return on Investment in manufacturing companies listed on the Indonesia Stock Exchange between before and after the 2008 tax reform. Based on the formulation of these hypotheses, the fifth hypothesis in this study is:

$\mathrm{H} 5$ : There is a difference in the profitability ratio (Return on Investment) before and after the tax amnesty until the third period.

\section{Difference in Tobin's $Q$ before and after tax amnesty}

The Tobin's $Q$ ratio is the ratio of the market value of the company's assets as measured by the market value of the number of outstanding shares and debt (enterprise value) replacement cost 
to the company's assets (Sudiyanto \& Puspitasari, 2010). Transfer of assets (repatriation) from abroad increases company assets. The higher the invested company assets, the greater the profit the company gets. Big profits can increase the value of a company. Research by Nabila and Nurdin (2019) stated that there was no significant difference in company value before and after tax amnesty in the textile and garment sub-sector companies. Based on the formulation of the hypothesis, the sixth hypothesis in this study is:

H6: There is a significant difference between company value and Tobin's $Q$ method before and after the tax amnesty until the third period.

\section{Methodology}

The data used in this research were secondary data which is quantitative in nature. While the source of data in this research were the annual report or the second quarter financial report which has been published and accessed through the website www.idx.co.id.

The population in this study were companies listed on the Indonesia Stock Exchange from 2016-2017. The sampling method in this study used purposive sampling. Purposive Sampling is a sample determination based on certain criteria (Suliyanto, 2005). Testing data used Paired Samples Test (Siregar, 2015). Through purposive sampling, the following data were obtained (Table 1).

\section{Results and discussion}

Testing the first hypothesis which states that there is a significant difference in the liquidity ratio (Current ratio) before and after the tax amnesty comes into effect until the third period. The results of the study are shown in Table 2.

Table 1. Data of Sample Selection Procedure

\begin{tabular}{cll}
\hline No. & Information & Qty. \\
\hline 1 & $\begin{array}{l}\text { Data of Property and Real Estate Company Listed on Indonesia Stock } \\
\text { Exchange 2016-2017. }\end{array}$ & 48 \\
2 & Not participating in the Tax Amnesty Program until the Third Period & (19) \\
3 & Financial reports that cannot be obtained & $(5)$ \\
4 & Not having Islamic shares listed on the IDX & $(7)$ \\
& Total of research observation & 17 \\
\hline
\end{tabular}


Table 2 shows the results of processed data using the test (paired sample t-test) with a significance of 0.05 , resulting in the statistical analysis which shows that before and after the third period of tax amnesty, the t count is 2.206 with a significance of 0.042 Sig.t $(0.042<0.050)$ so that the first hypothesis $(\mathrm{H} 1)$ is accepted and $(\mathrm{H} 0)$ is rejected.

The results of this study support the research conducted by Fauzan, Hendy and Windhi (2012) which states that there is a difference in the Current Ratio in manufacturing companies listed on the IDX before and after the tax reforms in 2008 (empirical study on manufacturing companies listed on the IDX) (Azhar et al., 2012). Another research conducted by Khatami et al. (2017) states that there is a significant difference in the Current Ratio between before and after the Initial Public Offering (IPO). Also, research conducted by Ariani et al. (2018) found that there is a difference in the Current Ratio between before and after tax amnesty in the textile and garment sub-sector companies.

The difference in Current Ratio in this study shows that these results are consistent with previous studies. This difference indicates that there is an increase in investment in the form of current assets obtained from the utilization of asset repatriation funds from the application of tax amnesty, while still being able to control current debt owned by the company. So, it has an impact on increasing the current ratio of the company.

The second hypothesis is that there is a significant difference in the leverage ratio (debt to equity ratio) before and after the third period of tax amnesty. The results of the study are shown in Table 3. Table 3 shows the results of the paired sample t-test for the Debt to Equity Ratio showing a significance of $0.065>0.05$, which means that $\mathrm{H} 2$ is rejected.

Table 2. Paired sample test of current ratio

\begin{tabular}{ll}
\hline \multicolumn{1}{c}{ Pair 1 } & \multicolumn{1}{c}{ CR_Before-CR_After } \\
\hline Mean & -0.81059 \\
Std. deviation & 1.18169 \\
Std. Error Mean & 0.28660 \\
95\% confidence interval & \\
Lower & -1.41815 \\
Upper & -0.20302 \\
T & -2.829 \\
Df & 16 \\
Sig. (2-tailed) & $0.012^{*}$ \\
\hline
\end{tabular}


The results of the research that support this research produce mixed results, some accept and some reject the hypothesis. Based on research conducted by Khatami et al. (2017), there is no difference in the Debt to Equity Ratio between before and after the Initial Public Offering (IPO) on the IDX.

It is different from research conducted by Azhar et al. (2012), which stated that there was a difference in the Debt to Equity Ratio in manufacturing companies listed on the IDX before and after the tax reform in 2008 (empirical study on manufacturing companies listed on the IDX). Research conducted by Ariani et al. (2018) found that there was a difference in Debt to Equity Ratio between before and after tax amnesty in textile and garment sub sector companies.

There is no difference in Debt to Equity Ratio in this study, indicating that this research is consistent with research conducted by Khatami et al. (2017). After participating in the tax amnesty, the average DER value decreased from 0.7471 to 0.7324 . This indicates that the implementation of tax amnesty by the government can reduce the debt burden on the company's own capital, which means that the smaller the debt to capital, the safer it is.

The third hypothesis, there is a significant difference in the activity ratio (Total Asset Turnover) before and after the third period of tax amnesty. The results of the study are shown in Table 4. In Table 4, the paired sample t-test for total asset turnover shows a significance of $0.039<0.05$, which means that $\mathrm{H} 3$ is accepted.

The results of the research that support this research produce a variety of studies, some accept and some reject the hypothesis. Based on research conducted by Khatami et al. (2017), the result

Table 3. Paired sample test of debt to equity ratio

\begin{tabular}{ll}
\hline \multicolumn{1}{c}{ Pair 1 } & \multicolumn{1}{c}{ DER_Before-DER_After } \\
\hline Mean & -0.11353 \\
Std. deviation & 0.23672 \\
Std. Error Mean & 0.5741 \\
95\% confidence interval & \\
Lower & -0.23524 \\
Upper & 0.00818 \\
T & -1.977 \\
Df & 16 \\
Sig. (2-tailed) & $0.065^{*}$ \\
\hline
\end{tabular}


Table 4. Paired sample test of total asset turnover (TATO)

\begin{tabular}{ll}
\hline \multicolumn{1}{c}{ Pair 1 } & \multicolumn{1}{c}{ TATO_Before-TATO_After } \\
\hline Mean & -0.4824 \\
Std. deviation & 0.8848 \\
Std. Error Mean & 0.2146 \\
95\% confidence interval & \\
Lower & -0.9373 \\
Upper & -0.00275 \\
T & -2.248 \\
Df & 16 \\
Sig. (2-tailed) & $0.039 *$ \\
\hline
\end{tabular}

stated that there was no difference in Total Asset Turnover before and after the Initial Public Offering (IPO). Then research conducted by Ariani et al. (2018) states that there is a difference in Total Asset Turnover before and after tax amnesty in the textile and garment sub sector companies.

The difference in Total Asset Turnover in this study shows that this result is consistent with the research conducted by Ariani et al. (2018). The average value, the average TATO has increased after participating in the tax amnesty for the first period to the third period from 0.3024 to 0.3294 . This difference indicates that the implementation of the tax amnesty policy carried out by the government can have an influence on the activity ratio as measured by TATO, which is indicated by an increase in company activity after the tax amnesty which increases the Total Asset Turnover in resulting in increased sales volume for the company.

The fourth hypothesis shows that there is a significant difference in the profitability ratio (Return on Equity) before and after the tax amnesty until the third period. The results of the study are shown in Table 5. Table 5 shows the results of the paired sample ttest for Return on Equity, showing a significance of $0.496>0.05$, which means that $\mathrm{H} 4$ is rejected.

Table 5. Paired sample test of return on equity (ROE)

\begin{tabular}{ll}
\hline \multicolumn{1}{c}{ Pair 1 } & \multicolumn{1}{c}{ ROE_Before-ROE_After } \\
\hline Mean & -0.02235 \\
Std. deviation & 0.13231 \\
Std. Error Mean & 0.03209 \\
95\% confidence interval & \\
Lower & -0.09038 \\
Upper & -0.04568 \\
T & -0.697 \\
Df & 16 \\
Sig. (2-tailed) & 0.496 \\
\hline
\end{tabular}


The result of this study is in line with Azhar et al. (2012) which states that there is no difference in Return on Equity in manufacturing companies listed on the IDX before and after the 2008 tax reform (empirical study on manufacturing companies listed on the IDX). Research by Khatami et al. (2017) found that there was a significant difference in Return on Equity between before and after the Initial Public Offering (IPO). Then research conducted by Ariani et al. (2018) stated that there was a difference in Return on Equity between before and after tax amnesty in the textile and garment sub-sector companies.

There is no difference in Return on Equity in this study, indicating that this study is consistent with research conducted by Fauzan et al. (2012). When it is viewed from the average value, the average ROE has decreased from 0.4388 to 0.4314 . This indicates that the implementation of the tax amnesty by the government until the third period doesn't cause a difference to the profitability ratio as measured by ROE because after the tax amnesty was implemented, the company's capital and net income had both increased (Rizki, Agriyanto, \& Farida, 2019). This statement can be proven by an increase in the amount of net income of several companies that have participated in the tax amnesty program until the third period. One of them was the BIPP Company which experienced an increase in net profit of around $10.66 \%$, i.e. Rp14,796,460,681 before the tax amnesty program was implemented and Rp16,374,209,990 at the time after the tax amnesty program was implemented.

The fifth hypothesis shows that there is a significant difference in the Profitability Ratio (Return on Investment) before and after the tax amnesty until the third period. The research results are shown in Table 6.

Table 6. Paired sample test of return on investment (ROI)

\begin{tabular}{ll}
\hline \multicolumn{1}{c}{ Pair 1 } & \multicolumn{1}{c}{ ROI_Before-ROI_After } \\
\hline Mean & -0.03176 \\
Std. deviation & 0.05823 \\
Std. Error Mean & 0.01412 \\
95\% confidence interval & \\
Lower & -0.06170 \\
Upper & 0.00183 \\
T & -2.249 \\
Df & 16 \\
Sig. (2-tailed) & $0.039 *$ \\
\hline
\end{tabular}


Based on Table 6, the paired sample t-test for Return on investment shows a significance of $0.039<0.05$, which means that $\mathrm{H} 5$ is accepted. The results of the study support the research by Fauzan et al. (2012) which states that there is difference in Return on Investment in manufacturing companies listed on the IDX before and after the 2008 tax reforms (empirical study of manufacturing companies listed on the IDX).

Rathih and Saparila's research (2018) states that there is a significant difference in Return on Investment before and after the merger and acquisition in 2013 (a study of companies listed on the IDX that carried out mergers and acquisitions in 2013). The average $\mathrm{ROI}$ has increased after following the tax amnesty in the first period to the third period, from 0.1582 to 0.1976 .

The higher the ROI, the better the company is, because it means the company is able to generate profits that are used to cover the investment issued. Several companies that participated in the tax amnesty program experienced an increase in their net income until the third period. BIPP Company experienced an increase in net profit after tax of around $10.66 \%$ to $R p 16,374,209,990$ from the previous amount of $\mathrm{Rp} 14,796,460.68$.

The sixth hypothesis shows that there is a significant difference in company value with the Tobin's $Q$ method before and after the third period of tax amnesty. The research results are shown in Table 7. In table 7 the paired sample t-test for company value calculated using Tobin's $Q$ ratio shows a significance of $0.019<0.05$, which means that $\mathrm{H} 6$ is accepted.

The results of the study contradict Rinaldi's (2017) research which resulted that the company value calculated by Price to Book Value and Tobin's $Q$ both decreased after the tax amnesty policy

Table 7. Paired sample test of Tobin's Q

\begin{tabular}{ll}
\hline \multicolumn{1}{c}{ Pair 1 } & \multicolumn{1}{c}{ ROI_Before-ROI_After } \\
\hline Mean & -2.91824 \\
Std. deviation & 4.59381 \\
Std. Error Mean & 1.11416 \\
95\% confidence interval & \\
Lower & -5.28016 \\
Upper & -0.55632 \\
T & -2.619 \\
Df & 16 \\
Sig. (2-tailed) & $0.019^{*}$ \\
\hline
\end{tabular}


was enacted. Research conducted by Nabila and Nurdin (2019) also stated that there was no significant difference in company value before and after the third period of tax amnesty in the textile and garment sub-sector companies.

The results showed that the calculation of Tobin's $Q$, from the 17 data studied, 11 data experienced an increase in Tobin's $Q$ value and 6 data experienced a decrease in Tobin's $Q$ value (from 1.1859 increased to 1.1928). This difference indicates that management has succeeded in managing company assets and the potential for investment growth is also increasing.

The total assets of several companies that have participated in the tax amnesty program increased until the third period. LPCK companies experienced an increase in total assets of around $11.48 \%$, i.e. Rp5, $583,843,268,624$ at the time before the tax amnesty was implemented and Rp6,225,096,276,320 at the time after the tax amnesty was implemented. The increase in company value will provide a good signal (good news) for investors to make investment decisions.

\section{Conclusion}

Based on the research results, it can be concluded that there is a significant difference in Current Ratio before and after the implementation of the tax amnesty program for the first period to the third period. There is no significant difference in Debt to Equity Ratio before and after the implementation of the tax amnesty program for the first period to the third period.

There is a significant difference in Total Asset Turnover between before and after the implementation of the tax amnesty program for the first period to the third period. There is no significant difference in Return on Equity between before and after the implementation of the tax amnesty program for the first period to the third period. There is a significant difference in Return on Investment between before and after the implementation of the tax amnesty program for the first period to the third period.

There is a significant difference between Tobin's $Q$ before and after the implementation of the tax amnesty program for the first period to the third period in the property and real estate sub-sector companies listed on the IDX. The research results prove that tax 
amnesty has an impact or influence on financial performance as measured by Current Ratio, Total Asset Turnover, Return on Investment and also on company value. Further researchers are advised to use more than one calculation model of company value and use more financial ratios to measure the company's financial performance (Agriyanto, Rohman, Ratmono, \& Ghozali, 2016; Awwaliyah, Agriyanto, \& Farida, 2019).

\section{References}

Agriyanto, R., Rohman, A., Ratmono, D., \& Ghozali, I. (2016). Accrual based accounting implementation: An approach for modelling major decisions. Risk Governance \& Control: Financial Markets \& Institutions, 6 (4), 531-539.

Ariani, Rina. Afufudin dan M. Cholid. "Analisis Perbandingan Kinerja Keuangan Sebelum dan Sesudah Diberlakukannya Tax Amnesty Periode Ketiga Tahun 2016 pada Perusahaan Sub Sektor Tekstil dan Garmen yang Terdaftar di BEl”. E-JRA. Vol 07. No 09. 2018.

Awwaliyah, N. F., Agriyanto, R., \& Farida, D. N. (2019). The effect of regional original income and balance funding on regional government financial performance. Journal of Islamic Accounting and Finance Research-Vol, 1(1).

Azhar, Fauzan, Hendy Izhar. Rella dan Widhi Yuniawan. "Analisis Kinerja Keuangan Perusahaan sebelum dan sesudah Reformasi Perpajakan Tahun 2008 (Studi Empiris : Perusahaan Manufaktur yang Terdaftar di BEI). Skripsi Fakultas Ekonomi Program Studi Akuntansi Ekstensi Universitas Indonesia. 2012.

Az-Zahra, Nabila Aulia dan Nurdin. "Analisis Perbandingan Nilai Perusahaan Sebelum dan Sesudah Kebijakan Tax Amnesty Periode Ketiga pada Perusahaan Sub Sektor Tekstil dan Garmen yang Terdaftar di BEl". Prosiding Manajemen. ISSN. 2460-6554. Vol 5. No 1. 2019.

Departemen Agama. Al - Qur'an dan Terjemahannya. PT Syamil Cipta Media. 2005.

Fahmi, Irham. Analisis Kinerja Keuangan. Bandung : Alfabeta. 2012.

Hery. Financial Ratio For Business, Jakarta : PT Grasindo, 2016.

Ikatan Akuntansi Indonesia. Akuntansi Aset dan Liabilitas Pengampunan Pajak, Jakarta: Pernyataan Standar Akuntansi Keuangan (PSAK 70), 2016.

Khatami, Nurbayitillah, Raden Rustam dan Sri Sulasmiyati. "Analisis Kinerja Keuangan Perusahaan Sebelum Dan Sesedah Initian Public 
Offering (IPO) DI bei”. Jurnal Administrasi Bisnis (JAB). Vol 47. No 1. 2017.

Law Number 28 Year 2007 about General Provisions and Taxation Article 1.

Rahardjo, Budi. Keuangan dan Akuntansi Edisi Petama. Cetakan Pertama. Yogyakarta : Graha IImu. 2007.

Rathih, Yan dan Saparila. "Analisis Perbandingan Kinerja Keuangan Sebelum dan Sesudah Merger dan Akuisisi Studi pada Perushaan yang Terdaftar di BEl yang Melakukan Merger dan Akuisisi pada Tahun 2013". Jurnal Administrasi Bisnis. Vol 62. No 2. 2018.

Renaldi, Muhammad. Signaling and Agency Theory. 2015.

Rinaldi. "Dampak Tax Amnesty Terhadap Laporan Keuangan dan Pengaruhnya kepada Nilai Perusahaan". Jurnal ADHUM. Vol VII. No 1. 2012.

Rizki, M. K., Agriyanto, R., \& Farida, D. N. (2019). The Effect of Sustainability Report and Profitability on Company Value: Evidence from Indonesian Sharia Shares. Economica: Jurnal Ekonomi Islam, 10(1), 117-140.

Siregar, Syofian. Metode Penelitian Kuantitatif: Dilengkapi Dengan Perbandingan Perhitungan Manual dan SPSS. Jakarta : Kencana. 2016.

Sudiyatno, Bambang dan Elen Puspitasari. “Tobin's Q dan Altman Z-Score Sebagai Indikator Pengukuran Kinerja Perusahaan, Kajian Akuntansi". Vol 2. No 1. 2010.

Suliyanto. Analisis Data Dalam Aplikasi Pemasaran. Bogor.: Ghalila Indonesia. 2005. 
Ratno Agriyanto \& Della Aprilia

JIEMB | 128

Journal of Islamic Economics, Management, \& Business-Vol 2. No.1 (2020) 